\title{
Tentative Cut Point of High-Sensitivity C-Reactive Protein for a Component of Metabolic Syndrome in Japanese
}

\author{
Eiji Oda, MD; Ryu Kawai, MD
}

\begin{abstract}
Background: High-sensitivity C-reactive protein (hs-CRP) is an independent risk factor of diabetes and cardiovascular disease, and is proposed as a component of metabolic syndrome (MetS). An optimal cut point of hs-CRP as a component of MetS was previously reported as $0.65 \mathrm{mg} / \mathrm{L}$ based on data from a small-sized study. Methods and Results: Medical check-up data of 1,062 men and 647 women whose plasma levels of hs-CRP were $<10 \mathrm{mg} / \mathrm{L}$ were examined using a receiver-operating characteristic (ROC) curve for diagnosing MetS, which was defined by revised NCEP criteria for Japanese. An optimal cut point was defined as the point on a ROC curve nearest to the point where both sensitivity and specificity were 1 . The area under the ROC curve of hs-CRP was 0.74 (95\% confidence interval (CI) $0.70-0.79)$ in men and 0.73 (95\%CI 0.66-0.79) in women. The optimal cut point of hs-CRP and its sensitivity-specificity were, respectively, $0.45 \mathrm{mg} / \mathrm{L}$ and $0.67-0.72$ in men and $0.25 \mathrm{mg} / \mathrm{L}$ and $0.71-0.62$ in women.
\end{abstract}

Conclusions: Among Japanese patients, a tentative cut point of hs-CRP as a component of MetS may be $0.45 \mathrm{mg} / \mathrm{L}$ in men and $0.25 \mathrm{mg} / \mathrm{L}$ in women. However, standardization of the measurement of hs-CRP is required. (Circ J 2009; 73: 755-759)

Key Words: High-sensitivity C-reactive protein; Inflammation; Metabolic syndrome; Obesity

$\mathbf{H}$ igh-sensitivity C-reactive protein (hs-CRP) has been reported as an independent risk factor of diabetes ${ }^{1}$ and cardiovascular disease ${ }^{2}$ and proposed as a component of metabolic syndrome (MetS) ${ }^{2}$. Levels of hs-CRP lower than $1 \mathrm{mg} / \mathrm{L}$, between $1 \mathrm{mg} / \mathrm{L}$ and $3 \mathrm{mg} / \mathrm{L}$, and higher than $3 \mathrm{mg} / \mathrm{L}$ are considered as low, intermediate and high risk category, respectively, in Western countries, 3 but hs-CRP levels in Japanese are substantially lower than those in Westerners. Previously, we reported $0.65 \mathrm{mg} / \mathrm{L}$ as an optimal cut point of hs-CRP as a component of MetS among Japanese ${ }^{4}$ and it seemed appropriate ${ }^{5-9}$ but the sample size was rather small, so we repeated the study in different subjects using different measurement methods and obtained a lower cut point of hs-CRP as a component of MetS. However, the median hs-CRP was also substantially lower than the previous value.

\section{Methods}

\section{Subjects}

Between April 1 and August 31 in 2008, 1,076 men and 650 women visited for routine medical check-ups. They were all required to fill out a questionnaire from the Ministry of Health, Labor, and Welfare for the purpose of "Special Health Examination and Instruction", including questions

(Received September 5, 2008; revised manuscript received November 5, 2008; accepted November 19, 2008; released online February 17, 2009)

Medical Check-up Center, Tachikawa Medical Center, Nagaoka, Japan

Grant: none.

Mailing address: Eiji Oda, MD, Medical Check-up Center, Tachikawa Medical Center, 2-2-16 Nagamachi, Nagaoka 940-0053, Japan. E-mail: ijie@venus.sannet.ne.jp

All rights are reserved to the Japanese Circulation Society. For permissions, please e-mail: cj@j-circ.or.jp about history of cardiovascular disease, smoking status, antihypertensive and hypoglycemic medications, and alcohol consumption. Of this group, 14 men and 3 women were excluded as subjects of the present study because their serum levels of hs-CRP were higher than $10 \mathrm{mg} / \mathrm{L}$. The protocol for the present study was approved by the Ethics Committee of Tachikawa Medical Center and signed informed consent was given by each subject.

\section{Measurements}

After an overnight fast, blood samples were taken to measure serum levels of glucose, triglyceride, high-density lipoprotein-cholesterol (HDL-C), low-density lipoproteincholesterol (LDL-C), hemoglobin A1c and uric acid, blood cell counts, electrolytes, liver and kidney function tests, including gamma glutamyltransferase, alkaline phosphatase, leucine aminopeptidase, cholinesterase, amylase, and hs-CRP. Biochemical measurements were all performed at BML Nagaoka (Nagaoka, Japan), except for hs-CRP, which was measured at BML General Laboratory (Tokyo, Japan), with nephelometry using N-latex CRP-2 (Siemens Healthcare Japan, Tokyo, Japan). The measurement limit of hs-CRP was $0.02 \mathrm{mg} / \mathrm{L}$ and the value of hs-CRP less than the measurement limit was considered as $0.01 \mathrm{mg} / \mathrm{L}$. Body fat percentage was measured by bioelectrical impedance analysis using TBF-210 (TANITA, Tokyo, Japan). An average blood pressure was calculated from 2 measurements with the subjects seated after 5 min rest. Body weight was measured with the subjects wearing light clothing provided by the Center and the weight of the clothes was subtracted from the measured body weight. Waist circumference (WC) was measured at the level of the umbilicus. Body mass index (BMI) was calculated as weight in kilograms divided by the square of height in meters. 
Table 1. Baseline Data

\begin{tabular}{|c|c|c|c|c|}
\hline & \multicolumn{2}{|c|}{$\operatorname{Men}(n=1,062)$} & \multicolumn{2}{|c|}{ Women $(n=647)$} \\
\hline & Mean \pm SD & Median & Mean \pm SD & Median \\
\hline Age, years & $51.7 \pm 9.3$ & 52.0 & $51.1 \pm 10.2$ & 51.0 \\
\hline BMI, $\mathrm{kg} / \mathrm{m}^{2}$ & $23.2 \pm 3.0$ & 23.0 & $21.6 \pm 3.2$ & 21.2 \\
\hline Body fat, $\%$ & $21.7 \pm 5.0$ & 21.5 & $26.5 \pm 5.9$ & 25.9 \\
\hline Waist circumference, $\mathrm{cm}$ & $83.9 \pm 8.3$ & 83.3 & $78.4 \pm 8.8$ & 77.3 \\
\hline Systolic blood pressure, $\mathrm{mmHg}$ & $121.4 \pm 16.8$ & 119.0 & $111.3 \pm 16.1$ & 108.5 \\
\hline Diastolic blood pressure, $\mathrm{mmHg}$ & $77.1 \pm 10.4$ & 76.5 & $69.5 \pm 10.0$ & 68.0 \\
\hline Fasting glucose, $\mathrm{mg} / \mathrm{dl}$ & $95.1 \pm 13.4$ & 92.0 & $89.5 \pm 11.3$ & 88.0 \\
\hline Triglyceride, $\mathrm{mg} / \mathrm{dl}$ & $117.8 \pm 81.5$ & 97.5 & $84.1 \pm 54.9$ & 72.0 \\
\hline HDL-cholesterol, $\mathrm{mg} / \mathrm{dl}$ & $57.9 \pm 14.6$ & 56.0 & $67.1 \pm 14.7$ & 65.0 \\
\hline hs-CRP, mg/L & $0.61 \pm 1.05$ & 0.28 & $0.42 \pm 0.73$ & 0.20 \\
\hline LDL-cholesterol, $\mathrm{mg} / \mathrm{dl}$ & $119.5 \pm 28.9$ & 119.0 & $119.5 \pm 28.8$ & 117.0 \\
\hline Antihypertensives, $\%$ & 17.9 & & 9.3 & \\
\hline Hypogycemics, \% & 3.6 & & 1.7 & \\
\hline Cardiovascular disease, $\%$ & 6.6 & & 3.4 & \\
\hline Current smoker, $\%$ & 33.8 & & 7.0 & \\
\hline MetS, \% & 13.2 & & 7.0 & \\
\hline JMetS, \% & 11.4 & & 1.7 & \\
\hline
\end{tabular}

BMI, body mass index; HDL, high-density lipoprotein; hs-CRP, high-sensitivity C-reactive protein; LDL, low-density lipoprotein. Metabolic syndrome (MetS) was defined according to the revised NCEP criteria for Japanese and Japanese metabolic syndrome (JMetS) was defined by the Examination Committee for Criteria of Metabolic Syndrome.

Table 2. Median hs-CRP Level According to the Number of MetS Components

\begin{tabular}{lccccc}
\hline \multirow{2}{*}{ Components } & \multicolumn{2}{c}{ Men } & & \multicolumn{2}{c}{ Women } \\
\cline { 2 - 3 } \cline { 5 - 6 } & $\mathrm{n}$ & Median hs-CRP $(\mathrm{mg} / \mathrm{L})$ & & $\mathrm{n}$ & Median hs-CRP $(\mathrm{mg} / \mathrm{L})$ \\
\hline 0 & 400 & 0.21 & 0.26 & 293 & 0.13 \\
1 & 318 & 0.39 & 214 & 0.24 \\
2 & 204 & 0.67 & 95 & 0.33 \\
3 & 92 & 0.66 & 33 & 0.42 \\
4,5 & 48 & & 12 & 0.57 \\
\hline
\end{tabular}

Abbreviations see in Table 1.

\section{Statistical Analysis}

MetS was defined according to the revised NCEP criteria ${ }^{10}$ as 3 or more of 5 components in which the cut point of WC was modified for Japanese as $\geq 90 \mathrm{~cm}$ in men and $\geq 80 \mathrm{~cm}$ in women according to the recommendation by the International Diabetes Federation (IDF) ${ }^{11}$ the cut points of the other components were systolic blood pressure $\geq 130 \mathrm{mmHg}$ and/or diastolic blood pressure $\geq 85 \mathrm{mmHg}$ for blood pressure, $\geq 150 \mathrm{mg} / \mathrm{dl}$ for triglyceride, $<40 \mathrm{mg} / \mathrm{dl}$ in men and $<50 \mathrm{mg} / \mathrm{dl}$ in women for HDL-C, and $\geq 100 \mathrm{mg} / \mathrm{dl}$ for fasting glucose. Subjects receiving antihypertensive or hypoglycemic medication were considered to have the respective component. Diagnosis of the Japanese MetS (JMetS) proposed by the Examination Committee for Criteria of Metabolic Syndrome ${ }^{12}$ was also performed. The median hs-CRP in each category defined by the number of MetS components was calculated. Receiver-operating characteristic (ROC) curve analysis for diagnosing MetS was performed to obtain the area under ROC curve (AUC) and an optimal cut point of hs-CRP for diagnosing MetS using Dr SPSS-2. An optimal cut point was defined as the point on a ROC curve nearest to the point where both sensitivity and specificity were 1 .

\section{Results}

Baseline data are shown in Table 1: 1,062 men aged 52士 9 (mean \pm SD) years and 647 women aged $51 \pm 10$ (mean \pm $\mathrm{SD})$ years were the subjects of the present study. The median
hs-CRP was $0.28 \mathrm{mg} / \mathrm{L}$ in men and $0.2 \mathrm{mg} / \mathrm{L}$ in women. The prevalence of MetS, JMetS, current smokers, and cardiovascular disease was $13.2 \%, 11.4 \%, 33.8 \%$, and $6.6 \%$, respectively, in men and $7.0 \%, 1.7 \%, 7.0 \%$, and $3.4 \%$, respectively, in women. Median hs-CRP in each category defined by the number of MetS components is presented in Table 2. The median hs-CRP in $0,1,2,3$, and 4 or 5 MetS components category was $0.21 \mathrm{mg} / \mathrm{L}, 0.26 \mathrm{mg} / \mathrm{L}, 0.39 \mathrm{mg} / \mathrm{L}$, $0.67 \mathrm{mg} / \mathrm{L}$, and $0.66 \mathrm{mg} / \mathrm{L}$, respectively, in men and $0.13 \mathrm{mg} / \mathrm{L}, 0.24 \mathrm{mg} / \mathrm{L}, 0.33 \mathrm{mg} / \mathrm{L}, 0.42 \mathrm{mg} / \mathrm{L}$, and $0.57 \mathrm{mg} / \mathrm{L}$, respectively, in women. ROC curves of hs-CRP for diagnosing MetS and JMetS are shown in Figure. The AUC of hs-CRP for diagnosing MetS and JMetS and the tentative optimal cut points of hs-CRP as a component of MetS and JMetS are presented in Table 3. The AUC of hs-CRP for MetS was 0.74 (95\% confidence interval (CI) $0.70-0.79)$ in men and 0.73 (95\% CI 0.66-0.79) in women. The AUC of hs-CRP for JMetS was 0.72 (95\%CI 0.67-0.77) in men and 0.75 (95\% CI $0.65-0.86)$ in women. The optimal cut point of hs-CRP as a component of MetS and JMetS was the same: $0.45 \mathrm{mg} / \mathrm{L}$ in men and $0.25 \mathrm{mg} / \mathrm{L}$ in women. The sensitivity-specificity was $0.67-0.72$ for MetS and $0.63-0.71$ for JMetS in men, and 0.71-0.62 for MetS and 0.77-0.60 for JMetS in women.

\section{Discussion}

For the past several decades, there has been considerable effort made to understand the underlying biology and to 

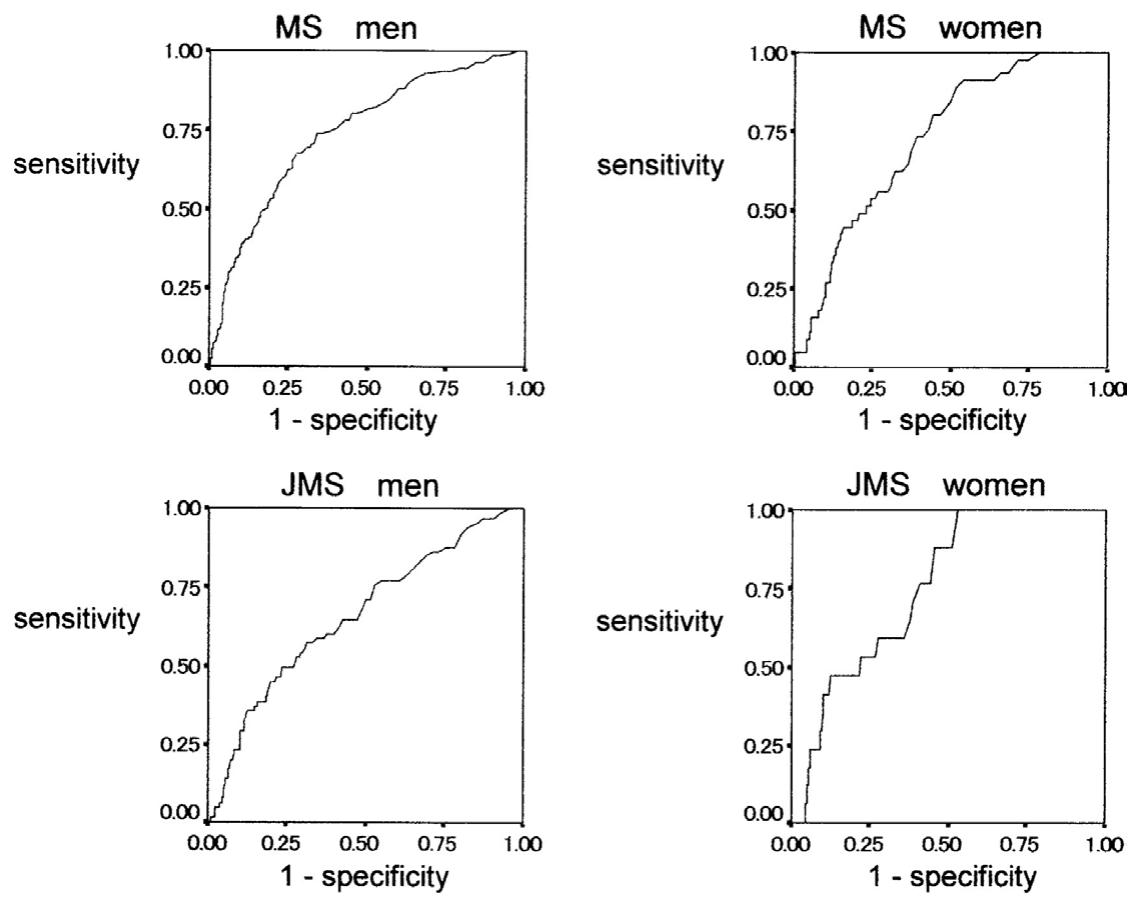

Figure. Receiver operating characteristic curves of high-sensitivity C-reactive protein for revised NCEP metabolic syndrome (MS) and Japanese metabolic syndrome (JMS).

Table 3. AUC and Optimal Cut Points of hs-CRP for MetS and JMetS

\begin{tabular}{llllll}
\hline & AUC & $95 \% \mathrm{CI}$ & Cut point & Sensitivity & Specificity \\
\hline Men & & & & & \\
MetS & 0.74 & $0.70-0.79$ & $0.45 \mathrm{mg} / \mathrm{L}$ & 0.67 & 0.72 \\
JMetS & 0.72 & $0.67-0.77$ & $0.45 \mathrm{mg} / \mathrm{L}$ & 0.63 & 0.71 \\
Women & & & & 0.71 & 0.62 \\
MetS & 0.73 & $0.66-0.79$ & $0.25 \mathrm{mg} / \mathrm{L}$ & 0.77 & 0.60 \\
JMetS & 0.75 & $0.65-0.86$ & $0.25 \mathrm{mg} / \mathrm{L}$ & \\
\hline
\end{tabular}

AUC, area under the receiver-operating characteristic curve; CI, confidence interval. Other abbreviations see in Table 1.

Table 4. Differences in Median or Geometric Mean hs-CRP Levels Among Different Studies of Japanese

\begin{tabular}{|c|c|c|c|c|c|c|c|c|}
\hline & \multicolumn{4}{|c|}{ Men } & \multicolumn{4}{|c|}{ Women } \\
\hline & hs-CRP (mg/L) & $\mathrm{n}$ & Age & BMI & hs-CRP (mg/L) & $\mathrm{n}$ & Age & BMI \\
\hline Yamada et $\mathrm{al}^{24}$ & $0.16(\mathrm{~A})$ & 2,275 & 55.8 & 22.8 & $0.09(\mathrm{~A})$ & 3,832 & 55.3 & 22.8 \\
\hline Doi et al ${ }^{1}$ & $0.49(\mathrm{~A})$ & 694 & 58 & 22.9 & $0.36(\mathrm{~A})$ & 1,065 & 57 & 23.0 \\
\hline Nakanishi et al ${ }^{5}$ & $0.53(\mathrm{~A})$ & 715 & 56.1 & 23.6 & $0.32(\mathrm{~A})$ & 988 & 55.8 & 22.0 \\
\hline Oda et $\mathrm{al}^{4}$ & $0.60(\mathrm{~A})$ & 179 & 52.0 & 23.8 & $0.30(\mathrm{~A})$ & 166 & 53.5 & 22.7 \\
\hline Present study & $0.28(\mathrm{~A})$ & 1,062 & 51.7 & 23.2 & $0.20(\mathrm{~A})$ & 647 & 51.1 & 21.6 \\
\hline Saito et $\mathrm{al}^{25}$ & 0.10 (B) & 398 & 69.0 & 23.2 & 0.08 (B) & 655 & 67.6 & 23.8 \\
\hline Nasermoaddeli et al ${ }^{26}$ & 0.42 (B) & 899 & & & 0.24 (B) & 780 & & \\
\hline Matsushita et al ${ }^{7}$ & $0.42(\mathrm{~B})$ & 2,523 & 48 & 23 & & & & \\
\hline
\end{tabular}

Age and BMI presented as mean; hs-CRP is presented as median (A) or geometric mean (B).

Abbreviations see in Table 1.

identify the risk factors of cardiovascular disease. As risk factors were identified, it became apparent that they tended to cluster in the same individual. Thus, the concept of insulin resistance syndrome (syndrome $\mathrm{X})^{13}$ or MetS ${ }^{14}$ emerged. MetS is a constellation of interrelated metabolic risk factors that appear to directly promote the development of diabetes and cardiovascular disease. The predominant underlying mechanisms of MetS appear to be insulin resistance, abdominal obesity, and inflammation. ${ }^{15}$ However, in 2005, the American Diabetes Association and the European Association for the Study of Diabetes jointly stated that no existing definition of MetS met the criteria of a syndrome ${ }^{16}$ and there have been endless debates on the pros and cons of diagnosing this syndrome in individuals. ${ }^{17-20}$ We thought MetS might develop through adipose tissue disease, 21 different from obesity, and therefore should be diagnosed with inflammatory, endocrine, metabolic, and histological tests. Criteria that regard anthropometry as an inevitable component of MetS have a serious pitfall, because there are a substantial number of metabolically obese normal weight individuals 22 and only approximately one-third of the most insulin-resistant individuals are actually obese ${ }^{19}$ In contrast, hs-CRP is an independent risk factor of cardiovascular disease and has been proposed as a component of MetS? 
In our previous study based on data from 179 men and 166 women, we reported $0.65 \mathrm{mg} / \mathrm{L}$ as an optimal cut point of hs-CRP for a component of MetS in both Japanese men and women, and this cut point seemed appropriate not only for diagnosing MetS5,6 but also for assessing cardiovascular risk? predicting coronary spasm $^{8}$, and differentiating nonalcoholic steatohepatitis from simple fatty liver? In the present study based on the data from 1,062 men and 647 women, we obtained $0.45 \mathrm{mg} / \mathrm{L}$ in men and $0.25 \mathrm{mg} / \mathrm{L}$ in women as the tentative optimal cut points as a component of MetS in Japanese. Although the measurement limit of hs-CRP was $0.1 \mathrm{mg} / \mathrm{L}$ and the median hs-CRP was $0.6 \mathrm{mg} / \mathrm{L}$ in men and $0.3 \mathrm{mg} / \mathrm{L}$ in women in our previous study, the measurement limit of hs-CRP was $0.02 \mathrm{mg} / \mathrm{L}$ and the median hs-CRP was 0.28 in men and 0.2 in women in the present study, though age, BMI and other basal data of the subjects were comparable between the 2 studies. Table 4 presents the medians or geometric means of the hs-CRP levels among Japanese reported in different studies. There are substantial differences among these reports despite similar ages and BMI of the study subjects. Therefore, the difference in the cut points of hs-CRP seemed to be mainly derived from differenced in the measurement methods. Standardization of hs-CRP measurement may be mandatory to establish an optimal cut point of hs-CRP as a component of MetS among Japanese. Though both the previous and the present hs-CRP cut points are very low compared with the standard in Western societies, 3 where obesity prevails, women with hs-CRP values equal to or higher than $0.5 \mathrm{mg} / \mathrm{L}$ have $\mathrm{s}$ higher risk of cardiovascular disease than women with hs-CRP values lower than $0.5 \mathrm{mg} / \mathrm{L}$, even in the United States ${ }^{23}$

As for gender differences in hs-CRP, Saltevo et al reported that the levels are significantly higher in women with MetS than in men with MetS, but in subjects without MetS, there are no gender differences in the level of hsCRP 27 Lakoski et al reported that women had substantially higher median hs-CRP levels compared with men.28 However, in Japan, hs-CRP levels among women without MetS are lower than the levels among men, but in subjects with MetS, the gender difference in the level of CRP might be obscured $4-6$ Thus, clustering of metabolic risk factors and weight gain may have stronger effects on the hs-CRP level in women than in men?

\section{Study Limitations}

The present study was a cross-sectional study and the subjects were not a general population, but visitors to a medical check-up center that is in a central city of a rural region in Japan. These conditions may have influenced the low serum levels of hs-CRP and the low prevalence of MetS and JMetS in these subjects. However, both the level of hs-CRP in the general population and the prevalence of obesity are very low in Japan. Therefore, the present data may not represent a peculiar population and the conclusions may be relevant to other regions and populations in Japan. As for the cut points of WC among Japanese, these are quite controversial ${ }^{29}$ When we examined JMetS using the WC cut point of $85 \mathrm{~cm}$ in men and $90 \mathrm{~cm}$ in women, as recommended by Japan Society for the Study of Obesity,30,31 the results were essentially the same. Standardization of hs-CRP measurement may be mandatory to determine an optimal cut point of hs-CRP as a component of MetS and longitudinal studies are required to establish hs-CRP as a risk factor of diabetes and cardiovascular disease in Japanese.

\section{Acknowledgment}

We thank Dr Shinpei Yoshii and Dr Masaaki Okabe at Tachikawa Medical Center for their effort to construct study environments and their review of the manuscript.

\section{References}

1. Doi Y, Wakugawa Y, Kiyohara Y, Yonemoto K, Kubo M, Iwase M, et al. Elevated C-reactive protein is a predictor of diabetes in a general Japanese population: The Hisayama study. Diabetes Care 2005; 28: $2497-2500$

2. Ridker PM, Wilson PWF, Grandy SM. Should C-reactive protein be added to metabolic syndrome and to assessment of global cardiovascular risk? Circulation 2004; 109: 2818-2825.

3. Pearson TA, Mensah GA, Alexander RW, Anderson JL, Cannon RO III, Criqui M, et al. Application to clinical and public health practice: A statement for healthcare professionals from the Centers for Disease Control and Prevention and the American Heart Association. Circulation 2003; 107: 499-511.

4. Oda E, Oohara K, Abe A, Veeraveedu PT, Watanabe K, Kato K, et al. The optimal cut-off point of C-reactive protein as an optional component of metabolic syndrome in Japan. Circ J 2006; 70: 384-388.

5. Nakanishi N, Shiraishi T, Wada M. C-reactive protein concentration is more strongly related to metabolic syndrome in women than in men: The Minoh study. Circ J 2005; 69: 386-391.

6. Saijo Y, Yoshioka E, Fukui T, Kawaharada M, Kishii R. Metabolic syndrome, C-reactive protein and increased arterial stiffness in Japanese subjects. Hypertens Res 2006; 29: 589-596.

7. Matsushita K, Yatsuya H, Tamakoshi K, Yang PO, Otsuka R, Wada $\mathrm{K}$, et al. High-sensitivity C-reactive protein is quite low in Japanese men at high coronary risk. Circ J 2007; 71: 820-825.

8. Itoh T, Mizuno Y, Harada E, Yoshimura M, Ogawa H, Yasue H. Coronary spasm is associated with chronic low-grade inflammation. Circ J 2007; 71: 1074-1078.

9. Yoneda M, Mawatari H, Fujita K, Iida H, Yonemitsu K, Kato S, et al. High-sensitivity C-reactive protein is an independent clinical feature of nonalcoholic steatohepatitis (NASH) and also of the severity of fibrosis in NASH. J Gastroenterol 2007; 42: 573-582.

10. Grundy SM, Cleeman JI, Daniels SR, Donato KA, Eckel RH, Franklin BA, et al. Diagnosis and management of the metabolic syndrome: A statement for health care professionals [an American Heart Association/National Heart, Lung, and Blood Institute Scientific Statement]. Circulation 2005; 112: 2735-2752.

11. Alverti KGMM, Zimmet P, Shaw J. Metabolic syndrome: A new world-wide definition [consensus statement from the International Diabetes Federation]. Diabet Med 2006; 23: 469-480.

12. The Examination Committee for Criteria of Metabolic Syndrome. Definition and criteria of metabolic syndrome. J Jpn Soc Intern Med 2005; 94: 794-809 (in Japanese).

13. Reaven GM. Role of insulin resistance in human disease. Diabetes 1988; 37: 1595-1607.

14. World Health Organization. Definition, diagnosis, and classification of diabetes mellitus and its complications: Report of a WHO Consultation. Geneva; WHO; 1999.

15. Dandona P, Aljada A, Chaudhuri A, Mohanty P, Garg R. Metabolic syndrome: A comprehensive perspective based on interactions between obesity, diabetes, and inflammation. Circulation 2005; 111: 1448 1454.

16. Kahn R, Buse J, Ferrannini E, Stern M. The metabolic syndrome: Time for a critical appraisal [joint statement from the American Diabetes Association and the European Association for the Study of Diabetes]. Diabetes Care 2005; 28: 2289-2304.

17. Grundy SM. Does the metabolic syndrome exist? Diabetes Care 2006; 29: $1689-1692$.

18. Kahn R. The metabolic syndrome (emperor) wears no clothes. Diabetes Care 2006; 29: 1693-1696.

19. Reaven GM. The metabolic syndrome: Is this diagnosis necessary? Am J Clin Nutr 2006; 83: 1237-1247.

20. Sattar N. Why metabolic syndrome criteria have not made prime time: A view from the clinic. Int J Obes 2008; 32(Suppl 2): S30-S34.

21. Oda E. The metabolic syndrome as a concept of adipose tissue disease. Hypertens Res 2008; 31: 1283-1293.

22. Ruderman NB, Schneider SH, Berchtold P. The "metabolicallyobese", normal-weight individual. Am J Clin Nutr 1981; 34: 1617 1621.

23. Ridker PM, Cook N. Clinical usefulness of very high and very low levels of C-reactive protein across the full range of Framingham risk scores. Circulation 2004; 109: 1955-1959. 
24. Yamada S, Gotoh T, Nakashima Y, Kayaba K, Ishikawa S, Naga N, et al. Distribution of serum C-reactive protein and its association with atherosclerotic risk factors in a Japanese population. Am J Epidemiol 2001; 153: $1183-1190$

25. Saito I, Yonemasu K, Imai F. Association of body mass index, body fat and weight gain with inflammation markers among rural residents in Japan. Circ J 2003; 67: 323-329.

26. Nasermoaddeli A, Sekine M, Kagamimori S. Intra-individual variability of high-sensitivity C-reactive protein: Age-related variation over time in Japanese subjects. Circ J 2006; 70: 559-563.

27. Saltevo J, Vanhala M, Kautiainent H, Kumpusalo E, Laakso M. Gender differences in C-reactive protein, interleukin-1 receptor antagonist and adiponectin levels in the metabolic syndrome: A population-based study. Diabet Med 2008; 25: 747-750.
28. Lakoski SG, Cushman M, Criqui M, Rundek T, Blumenthal RS, D'Agostino RB Jr, et al. Gender and C-reactive protein: Data from the Multiethnic Study of Atherosclerosis (MESA) cohort. Am Heart $J$ 2006; 152: 593-598.

29. Sato A, Asayama K, Ohkubo T, Kikuya M, Obara T, Metoki H, et al. Optimal cutoff point of waist circumference and use of home blood pressure as a definition of metabolic syndrome: The Ohasama Study. Am J Hypertens 2008; 21: 514-520.

30. The Examination Committee of Criteria for "Obesity Disease" in Japan. New criteria for "obesity disease" in Japan. Circ J 2002; 66: 987-992.

31. Oda E, Watanabe K. Japanese criteria of metabolic syndrome. Circ J 2006; 70: 364. 